\title{
Increasing Capacity Of Production And Innovation Of High Nutrition Of Black Meatball Products In Dolok Malela, Simalungun
}

\author{
Marini Damanik ${ }^{1 *}$, Fatma Tresno Ingtyas ${ }^{2}$, Wasis Wuyung Wisnu Brata ${ }^{3}$, Esi Emilia ${ }^{4}$, Ani \\ Sutiani $^{5}$ \\ ${ }^{1}$ Chemistry Department, Mathematics and Science Faculty, Universitas Negeri Medan \\ ${ }^{2,4}$ Currinary art Department, Engineering Faculty, Universitas Negeri Medan \\ ${ }^{3}$ Biology Department, Mathematics and Science Faculty, Universitas Negeri Medan \\ *marini@unimed.ac.id
}

\begin{abstract}
Community service activities with 2018 DRPM funds have been carried out in 3 stages. It started from licensing arrangements, handover of equipment and mentoring stage. This activity was carried out with the "Ubay" Meatball Milling Business Partner in Dolok Malela, Gunung Malela District. The need for meatball molding machines, meat grinding machines, and airtight plastic presses fulfilled. Besides, the meatball printing machine makes the meatballs produced the same size and the meatballs produced are smoother in texture. Furthermore, the provision of the airtight plastic press oriented to the stage of business expansion to preparing meatballs in the form of frozen meatballs. The method used to achieve the objectives of this service is the method of education, outreach and product standardization assistance. The output is grinding machines, meatball molding machines with standard size meatballs, knowledge of healthy and hygienic meatball-making procedures. Innovation is in making black meatballs and preparing meatballs for frozen food.
\end{abstract}

Keywords : black meatball, nutrition, frozen food

\section{Introduction}

One food source of animal protein that quickly found on the market is beef. Beef processing is usually like satay, soup or soup. Today, beef processing is extraordinary and is of interest to all age groups, namely meatballs. Making meatballs is not tricky, and its complementary ingredients are also natural to find.

Meatball processing requires the main ingredients in the form of fresh meat and other additives such as starch, salt, ice cubes, and other seasonings [1]. Fresh beef, flour and bamboo will be ground to form ground meat. Mixing the meat emulsion with starch flour, storage of the formed dough, molding the mixture into meatballs then cooking it in hot water to produce meatballs that are ready for consumption [2].

There are two kinds of techniques in making meatballs; the first technique is mixing all the ingredients and then destroying them (mixing and chopping) until a mixture formed - the second technique, crushing the meat and then mixing it with other ingredients. The purpose of the destruction of meat is to break down the cell wall of muscle fiber in the flesh so that it makes protein soluble and the salt extracted out [3]. 
Storage of the dough in the refrigerator for 10 minutes before being moulded into meatballs aims to increase the amount of soluble protein in the emulsion or meatball mixture to improve the physical properties of the resulting meatballs [4]. After making the dough, the moulding of the meatballs works by forming the dough into dots the size of marbles or more by using a hand or meatballs printing tool.

Besides, in cooking meatballs, two stages must be done. First, soaking the meatballs at a temperature of $50-60^{\circ} \mathrm{C}$ that aims to form the meatballs. Furthermore, the second stage, boiling the meatballs in water with a temperature of $100 \mathrm{oC}$, that aims to ripen the meatballs [3]. Cooking meatballs are done by boiling in boiling water or can also steam [5].

The cooking of meat must pay attention to the balance between high temperature and length of heating because the use of high heat with an extended period can cause changes in taste and thermal degradation of chemical components of food which can ultimately cause a decrease in quality. The fat melts, followed by the formation of volatile compounds during the heating process. In addition to that, there is also a reaction between the protein and the reducing sugars in the meat [6].

Innovations continue to be made continuously in the provision of these meatballs. Provision of meatballs with variations in a wide variety of stuffing, then giant size meatballs and phenomena with lambing meatballs. Currently, there are innovations in meatball products using color as an enchantment, namely black meatballs. The black color of meatballs can come from Japanese bamboo charcoal; our bamboo charcoal contains carbon that has been through the purification stage, making it safe for consumption and also suitable for health, for detoxification in the body [7].

Also, there is a black color, which comes from squid ink. The black color on squid ink is a natural black dye for various food dishes. Squid ink contains melanin compounds with very high concentrations and iron. Melanin is an amino acid that functions to activate our body's enzymes. The content of iron ( $\mathrm{Fe}$ ) in squid ink is beneficial in terms of nutrition and health. Iron is an essential mineral for our body, which makes up red blood cells (hemoglobin). Also, iron functions to help the function of muscles and brain, through its role to distribute oxygen in our body. ${ }^{8}$ One of the problems faced by the Ubay meatball mill is the small capacity of the meat grinding machine and the absence of a meatball printing machine. With the presence of a giant meat grinder and meatball molding machine, the Ubay meatball business can increase its production. One of the problems faced by the Ubay meatball mill is the small capacity of the meat grinding machine and the absence of a meatball printing machine. With the presence of a giant meat grinder and meatball molding machine, the Ubay meatball business can increase its production. The solutions offered to partners in the implementation of the Community Service Program are agreed to answer the main problems faced by partners in carrying out their business activities so that later an economically independent business will be formed. Justification for proposing partners explained as follows:

The solution to the supply of meatball grinding machines with higher capacity or more urgent needs is the meatballs forming machine so it will be seeking the supply of meatball forming machines.

The solution to the limited knowledge on the standardization process of the meatball processing will be held socialization and assistance on proper meatball processing procedures starting from the selection of raw materials used, the arrangement of production space, work standards and excellent and hygienic processing processes.

Solutions for diversifying meatball products and packaging design will be carried out with socialization and assistance in the process of producing black meatballs to increase the nutritional value of ordinary meatballs. 


\section{Methodology}

The method of implementation offered to partners to overcome the problems faced by partners is the method of education, training, outreach and assistance, including 1. Solutions for the supply of meatball molding machines and meatball grinding machines for higher capacity, efforts will be made to provide devices, 2. Solutions for the limited knowledge on the standardization process of the meatball processing, socialization and assistance will be held on right meatball processing procedures starting with the selection of raw materials used, the arrangement of production space, work standards and excellent and hygienic processing processes. 3. Solutions for the innovation of black meatball products and packaging design will be carried out with socialization and assistance in the process of producing black meatballs.

\subsection{Approach Method for Resolving Partner Issues}

Based on the problems that have been put forward, in this community service approach, the method used is the method of education, training, outreach and assistance. The purpose of the strategy offered to solve the problem operationally is as follows:

Observe a partner's business conditions to identify the issues faced regarding product standardization and certification; packaging used financial management and marketing systems. Provision of meatballs forming machines and meatballs primary grinding machines with larger capacities needed by partners.

Carry out socialization and assistance in the application of standardization in the production process by taking into account reasonable procedures for processing meatballs starting from the selection of raw materials used arrangement of production space, work standards and excellent and hygienic processing processes.

The several methods of the approach taken are in the first stage by surveying to find out the business conditions of partners with the technique of direct observation to the partner's location and conducting question and answer. This effort is carried out to find out the profile of partners and identify problems of partners. At this stage, partners play a role in preparing the data requested by the service team - furthermore, the approach method in processing practice. The processing process of providing meatball forming machines and grinding machines Basic ingredients of meatballs are available. The target to be achieved in this stage is the standard size of the meatballs and also the production of more meatballs. The role of partners in this stage seeks to prepare the required image of the meatball forming machine and grinding machine. The innovation of black meatball.

\section{Results and Discussion}

\section{Activity Results}

The condition of the "Ubay" meat grinder partners, partners want to develop this simple business by optimizing the manufacturing process and packaging of products that are more attractive, through effective and efficient innovation and appropriate technology so that the results of this meatball production can be an added value for the income of the general family and the people in this Dolok Malela-Simalungun in particular. 


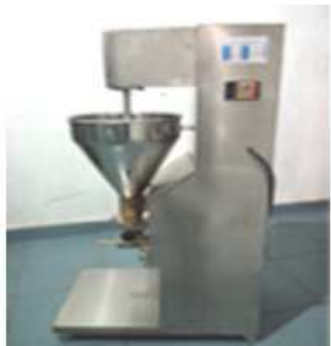

a. Meatball molding

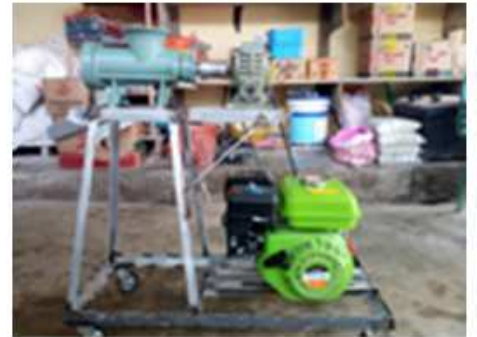

b. Meat grinder

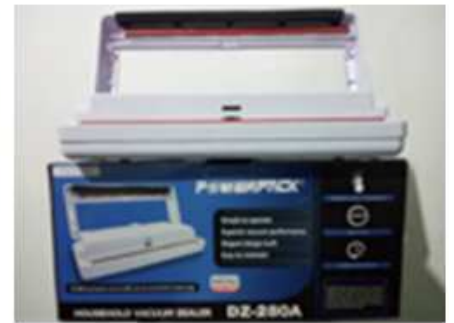

c. Soundproofing plastic press

Fig 1. Some machines are given to partners

Activities that apply innovation and appropriate technology in the process of printing meatballs. This meatball molding machine will produce meatballs of the same size and softer texture with greater production capacity. The machine is able to print meatballs in various sizes with the number of 280 seeds per minute for a standard size meatball (Figure 1a). Efficiency in terms of printing meatballs is very helpful for partners because it can save time when compared to printing meatballs manually by hand.
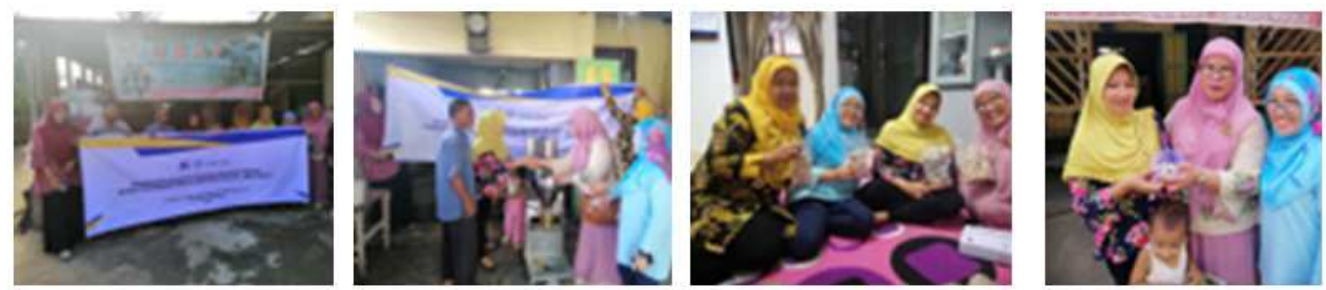

Fig 2. Giving instruments to "Ubay" Meatball Mill Partner

The effort to separate the meat grinder from the dough mixer for this micro-business also had a positive impact on partners. The use of the previous machine was less effective because the stages of making meatballs could not do at once. So if the grinding machine is running, the mixer is running by itself. Meanwhile, the meat must be ground first and then put into the dough machine. If a grinding machine is available (Figure 1b), the meat can be ground immediately and then put into a mixer. It is an opportunity to develop entrepreneurship together because the business opportunity for developing the meatball business is still wide open.

The provision of a vacuum sealer or an airtight plastic press (Figure 1c) has much helped the development of this meatball business. Bearing in mind, partners have only been selling meat grind and meatball dough directly without further development. This airtight press serves to package the product by exposing air in the packaging. So that making meatballs will remain safe, durable (durable), fresh, clean, and attractive within a few days if stored at room temperature and will be more durable if stored in the refrigerator. They are giving a sticker on the meatball packaging as an effort to increase the selling value of the meatballs.

On this occasion, the team introduced the making of black meatballs. Squid ink is rich in natural glutamic acid, so it tastes savory umami just like truffle and parmesan cheese. This squid ink can prevent fat oxidation that can reduce the risk of heart disease in humans. This black liquid is also found to be rich in iron. Iron is essential for producing hemoglobin and myoglobin, two proteins found in red blood cells to help deliver oxygen throughout the body. 
Giving squid ink does not produce fishy odor and also does not change the taste of the meatballs. Most of the people who have tasted the taste of black meatballs say that black meatballs taste more savory and delicious.

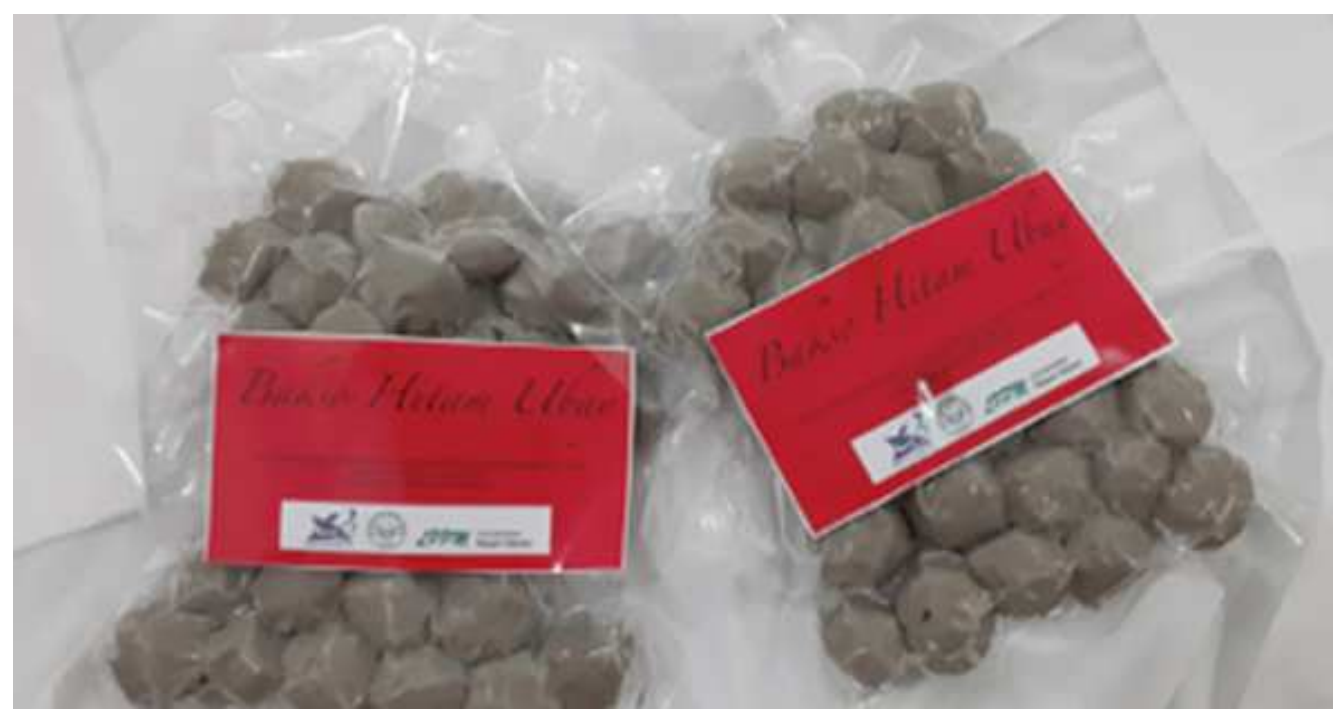

Fig 3. Ubay black meatball vacuum packaging design

The activity which has been going on for approximately 6 (six) months starting in in Dolok Malela-Simalungun involves 15 people, having various impacts felt by the Unimed LPPM team and the participants. The impact of activities can be in the form of direct impacts felt by the participants as well as indirect impacts.

The next stage of the process of implementing activities in community service activities is assistance. Assistance is carried out by meeting in person, also by communication via cell phones. Assistance 1 was carried out, where the head of the activity returned to the service location. It did in the process of mentoring as well as an evaluation. The review of the use of the equipment is carried out
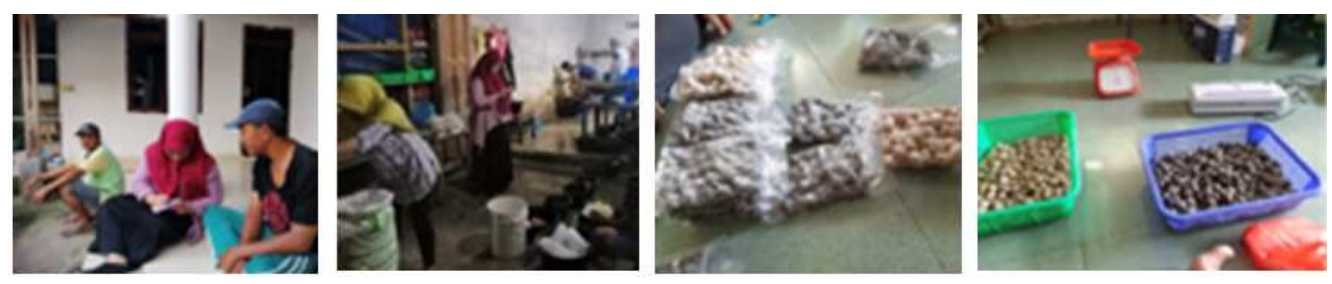

Fig 4. The using of the equipment applied

For the instructors (State University of Medan dedication team), this activity is part of the tri dharma of higher education that is community service. Lecturers, as one of the strategic components of the nation, also have a role in improving the quality of education, skills of citizens in the country. Also, the research conducted by the lecturers, the application of the research is in the form of community service. This form of dedication is the result of research 
conducted by previous lecturers. Thus, all material presented is the scientific result of the scientific thinking of the researchers.

The other impact from this activity for lecturers is a form and role by bringing the name of the State University of Medan. The midst of the community increasingly recognized and felt for its benefits. One strategy in introducing institutions to the world outside of campus is through community service activities because this activity is directly confronting the target community. For partners and meatballs traders, the impact is felt the efficiency at the stage of producing the meatballs which do not need a long time to form the meatballs. Furthermore, there is new knowledge about the innovation of making highly nutritious black meatballs.

\section{Conclusions}

Partners have given a meatball molding machine, a meat grinder and an airtight plastic press. Meatball product innovation with the addition of squid ink in the form of highly nutritious black meatballs. Knowledge and production skills of "frozen food" with the presence of an airtight plastic press. Packaging design to increase the selling value of black meatball products.

\section{Acknowledgement}

Thank you to Directorate of Research and Community Service (DRPM), Directorate General of Research and Development Strengthening of Indonesia. It is for providing funds so that this dedication can be carried out.

\section{References}

[1] Sunarlim, R. Characteristics of beef meatball quality and the effect of addition of $\mathrm{NaCl}$ and Sodium Tripolyphosphate on quality improvement. Dissertation. Postgraduate Program, Bogor Agricultural University, Bogor, (1992).

[2] Purnomo, H. Study of the quality of beef meatballs, vein meatballs and aci meatballs in the Bogor area. Essay. Faculty of Agricultural Technology, Bogor Agricultural University, Bogor (1990).

[3] Wilson, N. R. P., E. J. Dyet, R. B. Hughes \& C. R. Ve. Jones. Meat and Meat Product: Factors Affecting Quality Control. Applied Science Publishers, London dan New Jersey (1981).

[4] Indrarmono, T. P. Effect of length of withering and type of carcass meat and the amount of ice added to the dough on the physicochemical properties of beef meatballs. Thesis Department of Food and Nutrition Technology. Faculty of Agricultural Technology. Bogor Agricultural Institute (1987).

[5] Tarwotjo, I. S. Hartini, S. Soekirman \& Sumartono. The composition of three types of meatballs in Jakarta. Nutrition Academy. Jakarta (1971).

[6] Suradi, K. The potential and technological opportunities of rabbit product processing. Animal Husbandry Research Center, Bogor 16002. National Workshop on Potential and Rabbit Business Development Opportunities 16-17 (2004). 
[7] Dwimey, A. Black Meatballs, Healthy Foods Made From Japanese Bamboo Charcoal. [on line]. (https://lokalkarya.com/bakso-hitam-food-sehat-yang-terbuatfrom-arang-bambu-jAPAN.html, (2016).

[8] Sujarwo. Is cuttlefish or cuttlefish black ink safe for consumption? This is the Scientific Explanation [on line]. (http://jateng.tribunnews.com/2016/04/06/tintahitam-cumi-atau-sotong-apakah-aman-consumed-this-description- scientific-, accessed, (2016). 